A N N A LES
UNIVERSITATIS MARIAE CURIE-SKŁODOWSKA LUBLIN - POLONIA
VOL. XV, 2
SECTIO L

Wydział Ekonomiczno-Socjologiczny Uniwersytetu Łódzkiego

Ewelina Izabela WeJbert-Wąsiewicz

\title{
Feminizm w polskiej literaturze kobiet
}

Feminism in Polish Women's Literature

Przedmiotem rozważań w niniejszym szkicu są przede wszystkim wątki feministyczne obecne w polskiej literaturze kobiet. Autorka podejmuje refleksję dotyczącą następujących kwestii: czy istnieje zjawisko literatury feministycznej w Polsce; czy wątki feministyczne są charakterystyczne tylko dla sztuki kobiet; jakie feminizmy obecne są w literaturze kobiet?

\section{Feminizm w Polsce. Wprowadzenie}

Feminizm, a właściwie feminizmy - to kwestie niezwykle złożone. Nie chcąc zagłębiać się w kwestie historyczno-ideologiczne, można stwierdzić, że powszechnie występuje tendencja do wyróżniania kilku podstawowych orientacji ideologicznych. Feminizm liberalny dąży do zrównania kobiet i mężczyzn w świetle prawa oraz do stworzenia idealnego, neutralnego ustroju państwowego, gdzie podejmowane przez człowieka role społeczne pozbawione będą podziału na kategorie męskie i żeńskie. Tę sytuację ma ułatwić emancypacja kobiet i zreformowanie prawodawstwa. Feminizm radykalny wiąże się z postulatami potrzeby ogólnych zmian społeczno-politycznych opartych na kobiecym sposobie postrzegania rzeczywistości. Zmiany mają mieć charakter rewolucyjny i dotyczyć całego społeczeństwa 
a wyzwolenie kobiet musi nastąpić zarówno w sferze publicznej, jak i prywatnej. Męska dominacja jest bowiem podstawą wszelkiej opresji na świecie. Feminizm umiarkowany za cel swojej działalności przyjmuje skuteczność działania na rzecz poprawy jakości życia kobiet. Akceptuje pogląd, że płcie wzajemnie się uzupełniają. Feminizm kulturowy dostrzega maskulinizm języka, kultury oraz nauki i dlatego dąży do zmiany poprzez poszukiwanie żeńskiej formy wypowiedzi i duchowej twórczości ${ }^{1}$. Różnice między wspomnianymi feminizmami polegają na uznawaniu odmiennych metod zmiany sytuacji społecznej kobiet.

Feminizm radykalny nigdy nie znajdował w Polsce poparcia. Taką tendencję zaobserwować można również obecnie. Natomiast najczęściej akceptowane są postulaty feminizmu liberalnego, umiarkowanego².

Postawy polskich kobiet względem feminizmu były określone przez historyczno-kulturowo-narodowe tradycje i okoliczności. Polki przez wiele lat znajdowały się w odmiennej sytuacji niż kobiety w zachodnich krajach Europy, głównie z powodu walki wyzwoleńczej narodu. Pierwszy Zjazd Związku Kobiet Polskich miał miejsce 19 października 1905 roku w Warszawie ${ }^{3}$, ale należy podkreślić, że już znacznie wcześniej organizowano nieoficjalne zjazdy kobiet w trzech zaborach ${ }^{4}$. Wówczas głównym hasłem feministek polskich pozostawało równouprawnienie obywatelskie. Oprócz walki o prawa wyborcze podnoszono także kwestię edukacji kobiet i wychowania, pracy kobiet, ich udziału w życiu politycznym. Ruch kobiecy funkcjonował w postaci wielu stowarzyszeń, komitetów, organizacji samopomocowych, a także pism feministycznych („Ster”, „Nowe Słowo”).

We współczesnej Polsce najbardziej doniosły przejaw działalności ruchu żeńskiego stanowi Kongres Kobiet Polskich, który odbywa się corocznie od 2009 roku i gromadzi tysiące uczestniczek z całego kraju. W ramach wydarzenia organizowane są wykłady, panele dyskusyjne, debaty plenarne. Efektem tych działań są konkretne postulaty mające na celu poprawę sytuacji kobiet w Polsce oraz Gabinet Cieni Kongresu Kobiet Polskich monitorujący działania polityków. Siła politycznego oddziaływania Gabinetu Cieni jak i całego ruchu pozostaje raczej niewielka. Świadczą o tym sporadyczne spotkania środowiska z rządzącymi i losy wcześniej założonej Partii Kobiet. Partia utworzona przez pisarkę Manuelę

${ }^{1}$ K. Ślęczka, Feminizm. Ideologie i koncepcje społeczne współczesnego feminizmu, Katowice 1999 , s. 482.

${ }^{2}$ M. Frąckowiak-Sochańska, Postawy polskich kobiet wobec feminizmu. O samo ograniczajacej się świadomości feministycznej kobiet, „Acta Universitatis Lodziensis. Folia Sociologica” 2011, nr 39, s. 149-170 i wskazana tam literatura.

${ }^{3}$ I. Desperak, M. Sikorska-Kowalska, G. Matuszak, Emancypantki, włókniarki i ich bohaterki. Znikajace kobiety, czyli biate plamy naszej historii, Pabianice 2009.

${ }^{4}$ Ibid., s. 11. 
Gretkowską w wyborach parlamentarnych w 2007 i w 2011 roku nie przekroczyła w głosowaniu do sejmu progu wyborczego. Natomiast warto wspomnieć o działalności Federacji na rzecz Kobiet i Planowania Rodziny, która zajmuje się prawami reprodukcyjnymi Polek od 1992 roku. Organizacja skupia kilka środowisk kobiecych takich, jak Liga Kobiet Polskich, Związek Dziewcząt i Kobiet Chrześcijańskich, Polskie Stowarzyszenie Feministyczne, Stowarzyszenie Neutrum5. Biorąc pod uwagę feministyczną działalność piśmienniczą, należy zaakcentować, że choć w sieci funkcjonują różnorodne, feministyczne strony internetowe (np. „Feminoteka”), blogi (np. „bez jaj”), witryny pism elektronicznych (np. ,artmix”, „Interalia”, „Unigender”) jedynym feministycznym czasopismem polskim ukazującym się od 1999 roku pozostaje „Zadra”.

Badania socjologiczne pokazują, że w Polsce feminizm nie jest powszechnie aprobowany nawet wśród kobiet, które doświadczają nierówności płci ${ }^{6}$. Natomiast powszechnie ma miejsce dystansowanie lub negowanie pozytywnej roli feministki, a przede wszystkim brak wiedzy na temat feminizmu znajdujący wyraz w stereotypowych przekonaniach. Badaczka ruchów feministycznych Ewa Malinowska wiele lat temu postawiła tezę, że polski ruch feministyczny jest zbiorem indywidualnych podmiotów, a nie zbiorowym aktorem społecznym ${ }^{7}$. Czy w Polsce istnieje zatem sztuka feministyczna?

Dla sztuki feministycznej charakterystyczne jest zaangażowanie w sprawy kobiet, a wraz z tym dążenie do przemiany w systemie dyskryminacji. Feminizm wpisuje się w obszar sztuki atakującej, prowokującej, podkreślającej znaczenie seksualności jako siły, dzięki której kobiety mogą przeciwstawić się patriarchalnemu światu. Najszybciej idee feministyczne przeniknęły do polskiej literatury.

\section{Literatura i feminizm}

Krytycy od lat podkreślają pożytki i wady wynikające z uwzględnienia płci jako kryterium literatury. Stawiają pytania o inne kryteria tejże literatury. Współczesna badaczka Grażyna Borkowska opisując literaturę kobiecą, użyła metafory drożdży ${ }^{8}$. Kilkadziesiąt lat wcześniej Irena Krzywicka mówiła o „kobiecym

\footnotetext{
${ }^{5}$ Na podstawie: Statut Federacji na Rzecz Kobiet i Planowania Rodziny http://www.federa.org. $\mathrm{pl} /$ index.php?option $=$ com_content\&view $=$ article\&id=65\&Itemid $=70$ [dostęp: 12.11 .2012 ].

${ }^{6}$ Frąckowiak-Sochańska, op. cit., s. 154.

${ }^{7}$ E. Malinowska, Kobiety i feministki, „Kultura i Społeczeństwo” 2001, nr 2, s. 21.

${ }^{8}$ G. Borkowska, Metafora drożdży. Co to jest literatura/poezja kobieca?, [w:] Ciało i tekst. Feminizm w literaturoznawstwie - antologia szkiców, red. A. Nasiłowska, Warszawa 2001, s. 36.
} 
jazgocie”. Maria Janion pisała o „duchu inności” kobiet, udowadniając, że żeńską podmiotowość wykluczano w kulturze ${ }^{10}$. Przemysław Czapliński polemizował z tym stanowiskiem, a samą literaturę kobiecą pojmował za Ewą Kraskowską niczym konwencję literacką ${ }^{11}$. Wyodrębnienie literatury kobiecej jako osobnego zjawiska społecznego dla socjologów nie jest zabiegiem „sztucznym”. Płeć (sex i gender) autora/autorki pozostaje zmienną niezależną, której wpływ na dzieło chcemy zbadać. Oglądowi podlegają zarówno wybrane dzieła, kontekst społeczno-kulturowy, jak i dziedzictwo minionych pokoleń i zależności między nimi oraz związki z ideami feministycznymi.

Literatura polska oficjalnie $\mathrm{z}$ feminizmem związana jest od powstania Ruchu Entuzjastek, czyli od lat 30. XIX wieku. Wówczas pisarki z Narcyzą Żmichowską na czele zajmowały się działalnością publicystyczną, edukacyjną i polityczną, a emancypację kobiet postrzegały jako nierozdzielną z wyzwoleniem narodu. Pisarki tego okresu zaangażowane w walkę o prawa kobiet to m.in.: Maria Konopnicka ${ }^{12}$, Eliza Orzeszkowa ${ }^{13}$, Maria Ilnicka (pisarka, thumaczka, redaktorka „Bluszczu”), Emilia Gosselin (autorka gramatyki języka polskiego), Anna z Sokołowskich Skimborowiczowa (autorka literatury dziecięcej), Bibianna Moraczewska (publicystka, działaczka konspiracyjna).

Kolejne pokolenia literatek polskich reprezentowały różne odmiany feminizmu, opisując zawsze problemy kobiet. Ogólnie można jednak zauważyć, że stałym rysem ich twórczości literackiej były idee patriotyczne, co wiązało się z sytuacją polityczną, historyczną, społeczno-kulturową naszego kraju. Poetki publikowały pod pseudonimem męskim (np. Zofia Trzeszczkowska jako Adam M-ski) bądź nie ukrywały swej płci przed cenzurą (np. Kazimiera Zawistowska, Marcelina Kulikowska). Analizując biografie, dzieła Zawistowskiej i Kulikowskiej (zginęły śmiercią samobójczą) można wysnuć tezę, że ich działalność twórcza nie była w stanie zrekompensować ograniczeń, jakie ówczesna kultura kładła na barki kobiet ${ }^{14}$.

${ }^{9} \mathrm{~K}$. Grzybczyk, O literaturze kobiecej Dwudziestolecia międzywojennego. Rekonesans badawczy, [w:] Czytanie Dwudziestolecia, red. nauk. E. Hurnikowa i A.Wypych-Gawrońska, Częstochowa 2005 , s. 239-249.

${ }^{10}$ M. Janion, Kobiety i duch inności, Warszawa 1996.

${ }^{11}$ O tak zwanej kobiecości jako konwencji literackiej, [w:] Krytyka feministyczna. Siostra teorii i historii literatury, red. G. Borowska i L. Sikorska, Warszawa 2000, s. 205; P. Czapliński, Kobiety i duch tożsamości, [w:] Idem, Efekt bierności. Literatura w czasie normalnym, Kraków 2004, s. 98.

${ }^{12}$ Zob. L. Magnone, Konopnicka. Lustra i symptomy, Gdańsk 2011; M. Konopnicka, Listy do synów i córek, oprac. L. Magnone, Warszawa 2010.

${ }^{13}$ Ważnym przykładem emancypacyjnej prozy jest Marta Elizy Orzeszkowej - kobiece studium psychologiczne.

${ }^{14}$ Oficjalnie jako przyczynę zgonu podawano „rozstrój nerwowy”, ale z pozostawionych dokumentów osobistych, listów wiadomo, że możliwość zdobywania wiedzy i pracy, a z drugiej strony 
Ignacy Fik twierdził, że po I wojnie światowej naprawdę zaistniała u nas „literatura kobieca" ${ }^{15}$. Wówczas nastąpiła jakoby erupcja kobiecych talentów. Pisarki zdobyły popularność, poczytność i uznanie krytyków (np. Helena Boguszewska, Ewa Szelburg-Zarembina, Wanda Melcer, Wanda Miłoszewska, Hermina Neglerowa, Maria Ukniewska). Dzięki przemianom obyczajowo-społecznym zwiększył się udział kobiet w literaturze, co zaowocowało wprowadzeniem do literatury tematów z tzw. „domowej lampy” i poetyki codzienności. Dla mężczyzn były to tematy błahe i dlatego nieopisywane.

Dzięki żeńskiej twórczości dokonała się nobilitacja małych zdarzeń dnia codziennego (np. w utworach Całe życie Sabiny H. Boguszewskiej, Walka z miłościa I. Krzywickiej, Święta kucharka W. Melcer). Okres dwudziestolecia międzywojennego, a w szczególności prawa wyborcze i oświatowe dla kobiet sprawiły, że pojawiły się udane próby przezwyciężenia różnych tabu, np. związanych z seksualnością, ciążą, macierzyństwem, aborcją ${ }^{16}$, małżeństwem, o czym świadczą dzieła G. Zapolskiej, Z. Nałkowskiej, M. Kuncewiczowej, P. Gojawiczyńskiej, I. Krzywickiej, A. Gruszeckiej, H. Boguszewskiej i wielu innych.

Jedną z pionierek i gorszycielek była Irena Krzywicka, która jako pierwsza uznała za ważne dla literatury takie tematy jak menstruacja (Pierwsza krew, 1933), czy antykoncepcja (Walka z miłościa, 1936). Lata 30. XX wieku to także czas, gdy Maria Dąbrowska napisała sagę rodzinną z narracją kobiecą (Noce i dnie) a Maria Jasnorzewska-Pawlikowska podjęła się w poezji i dramatach opisu tematów bulwersujących politycznie i obyczajowo, stając po stronie krzewicieli idei świadomego macierzyństwa (takich jak Irena Krzywicka i Tadeusz Boy-Żeleński). Skandaliczne dla opinii publicznej tematy seksualne charakteryzowały również prozę Gabrieli Zapolskiej czy Wandy Melcer (Swastyka i dziecko, Wrzesień kobiety).

Zasługą pisarek tego okresu były pierwsze literackie opisy ciąż, porodów i samotnego macierzyństwa. Literatki dwudziestolecia międzywojennego ukazywały także wady mężczyzn i słabości systemu, m.in. skłonność do zdrady i przemocy, opuszczanie żon, brak odpowiedzialności za ciążę.

W literaturze tego okresu reprezentowanej przez kobiety wyraźnie uwidaczniał się feminocentryzm, który przejawiał się w widzeniu całej rzeczywistości przez pryzmat osobowości kobiecej.

Druga wojna światowa przesłoniła idee feministyczne, tematy i wątki uznawane za kobiece. Powojenne Medaliony Zofii Nałkowskiej pisane były z perspektywy uniwersalistycznej. Powstało wówczas wiele utworów będących

społeczne stereotypy i ograniczenia praw kobiet w dużym stopniu przyczyniły się do ostatecznego dramatu. Zob. A. Brożkowska, Marcelina Kulikowska. Strzat w serce, [w:] Śladami Marceliny Kulikowskiej. Małopolska w reportażach, red. E. Furgał, Kraków 2010.

${ }^{15}$ I. Fik, Dwadzieścia lat literatury polskiej (1918-1939), Kraków 1939.

${ }^{16}$ Zob. E. Wejbert-Wąsiewicz, Aborcja w dyskursie publicznym, Łódź 2012, s. 105-140. 
Pobrane z czasopisma Annales L - Artes http://artes.annales.umcs.pl

Data: 26/04/2023 14:33:46

102

Ewelina Izabela Wejbert-Wąsiewicz

rozrachunkiem z przeszłością. Tym samym feministyczne tradycje zostały zapomniane na wiele lat. Amnezji sprzyjał komunistyczny mit równouprawnienia.

Warto w tym miejscu wspomnieć, że dziś zupełnie nieznane pozostają nazwiska popularnych niegdyś powieściopisarek dla dzieci i młodzieży, poetek, nowelistek, autorek literatury dydaktycznej z okresu pozytywizmu takich, jak np. Wilhelmina Zyndram-Kościałkowska (1844-1926); Jadwiga Popi (1844-1906); Zofia Urbanowska (1849-1939); Józefa Ostója (1859-1920), z okresu Młodej Polski np. Emma Dmochowska (1864-1919); Helena Pajzderska (1862-1927); Maria Rodziewiczówna (1863-1944), z czasów dwudziestolecia międzywojennego np. Bronisława Ostrowska (1881-1928); Kazimiera Iłłakowiczówna (1888-1983). Wśród poetek niesłusznie zapomnianych wymienić można Kazimierę Zawistowską (1870-1902), Marylę Wolską (1873-1930), Marię Komornicką (1876-1949), Marcelinę Kulikowską (1872-1910). Ostatnia ze wspomnianych była też jedną z pierwszych w Polsce dziennikarek ${ }^{17}$.

Interesujący jest fakt, że z kanonu wyparto twórczość jednej z najwybitniejszych poetek młodopolskich ${ }^{18}$, autorki Biesów, jak i jej rówieśniczki Heleny Mniszkówny (1878-1943), królowej romansów literackich, autorki czterokrotnie filmowanej Trędowatej. Nie zawsze powodem wspomnianego „niebytu” jest moda, słaba jakość utworów czy ich ,przemijalność czasowa”. Bezpośrednio po śmierci twórczyń o dziedzictwo literackie, niekiedy rozproszone, nie miał kto zadbać. Jeszcze inną kwestią pozostawała cenzura dzieł, wycofanie książek pisarek z publicznego obiegu w okresie PRL.

W latach 60. i 70. XX wieku w Polsce debiutowały twórczynie literatury popularnej, np. autorka powieści sensacyjnych Joanna Chmielewska (Klin, 1964); pisarka i felietonistka Krystyna Kofta (Lustro, 1976); powieściopisarka i nowelistka Maria Nurowska (Nie strzelać do organisty, 1974). Są to autorki, które jakby „,na nowo" wprowadziły silne bohaterki do literatury polskiej, ukazując w szczególności ich portret psychologiczny, wewnętrzny świat uczuć i doświadczeń. W poezji w tym okresie kwestie kobiece dobitnie ukazywały Anna Świrszczyńska i Halina Poświatowska. Obie pisały o tym, jak to jest „być kobietą”. Poświatowska koncentrowała się na opisach uczuć, namiętności, drobnych przyjemności, kruchości i siły kobiet, ich codzienności, doświadczaniu swego ciała ${ }^{19}$. Świrszczyńska w poezji odmalowała bohaterki, siłaczki, „damskie ciała”, ale i skrzywdzone przez patriarchat „siostry”. Były to obrazy „inności” kobiety i jej „nierówności”20.

\footnotetext{
${ }^{17}$ Zob. Śladami Marceliny Kulikowskiej. Małopolska.

${ }^{18}$ Zob. I. Filipiak, Obszary odmienności. Rzecz o Marii Komornickiej, Gdańsk 2007.

${ }^{19}$ Zob. K. Karasiewicz, Halina Poświatowska w zwierciadle swej kobiecości, Kraków 2008.

${ }^{20}$ Kategorie [za:] Czapliński, op. cit.
} 
Po 1989 roku w kraju dokonała się „rewolucja” poprzez zaistnienie pisarek opisujących najbliższe doświadczenia kobiece, ale także otwarcie deklarujących w wywiadach feminizm, np. Manuela Gretkowska, Izabela Filipiak, Olga Tokarczuk, Natasza Goerke. Z ważnych literatek debiutujących w latach 90. wymienić należy także Małgorzatę Saramonowicz, Magdalenę Tulli, Zytę Rudzką. Przyglądając się tematom poruszanym przez piszące kobiety, nietrudno zauważyć, że kobieca bohaterka, żeńska narracja, wewnętrzne przeżycia kobiet są charakterystycznym rysem ich twórczości. Specyficzna kobieca narracja pojawiła się już wcześniej, bo u pisarek, które debiutowały w latach 70. i 80. np. Hanna Krall (1972, Na wschód od Arbatu), Ewa Kuryluk (1974, Wiedeńska apokalipsa), Anna Nasiłowska (1977, poezja), Hanna Kowalewska (1985, poezja), Anna Bolecka (1989, Leć do nieba). Jednakże literatura tworzona przez debiutantki z lat 90., zazwyczaj związane z „bruLionem”, stawiała bezpośrednie pytania o feminizm, ciało, specyfikę płci, konfrontacje płci.

Klucz feministyczny nie jest zapewne jedyną możliwością odczytywania pisarstwa kobiet debiutujących w okresie transformacji (tj. I. Filipiak, N. Goerke, M. Gretkowska, Z. Rudzka, A. Nasiłowska). Różnorodność tematów i wątków wydaje się olbrzymia. Dla przykładu można przywołać kilka wytworów opisywanej tu literatury. Teresa Lubkiewicz-Urbanowicz stworzyła w latach 90. anachroniczną powieść o Kresach pt. Boża podszewka. Ta historia rodu z mocnymi bohaterkami dopiero po sfilmowaniu doczekała się uznania ${ }^{21}$. Inna debiutantka tego okresu Olga Tokarczuk w każdym utworze starała się wprowadzić kobiecy punkt widzenia, mitologię, opisać historię, los kobiety. Strategie pisarskie pewnych twórczyń oscylują wokół uniwersalnych kwestii. Hanna Krall od lat zajmuje się etycznymi rozważaniami nad historią i kulturą, a Ewa Kuryluk postmodernizmem. Psychoanalityczne wątki interesują Zytę Rudzką, Annę Nasiłowską, Annę Bolecką, Małgorzatę Saramonowicz, Hannę Kowalewską, Hannę Samson. Niezależnie od różnych zainteresowań, prywatnych doświadczeń i inspiracji kulturą żeńskie ,ja” wybrzmiewa we wszystkich ich utworach.

Najważniejsze powieści rozpoczynające epokę transformacyjną dotyczyły emigracji, np. My zdies emigranty (1991) M. Gretkowskiej, Absolutna amnezja (1995) I. Filipiak. Termin „feminizm” nie pada ani razu w tekstach Gretkowskiej i Filipiak. Maria Janion słusznie zauważyła, że krytyka początkowo pomijała kategorie feministycznej analizy ${ }^{22}$. Motto Gretkowskiej: ,,mojej żonie” uruchomiło proces analizy podmiotowości kobiety w kulturze. Przemysław Czapliński pisał,

${ }^{21}$ Kontynuacją tematu jest zbiór opowiadań Babskie nasienie, wzbogacony o wątki autobiograficzne.

${ }^{22}$ M. Janion, Kobiety i duch inności, Warszawa 1996, s. 327-338. 
że była to raczej książka indywidualistyczna niż feministyczna ${ }^{23}$. Znany krytyk Jan Błoński nazwał pisarstwo Filipiak „literaturą menstruacyjną”24. Trzeba podkreślić, że opisy cielesności kobiecej, niezwykle intymnej i przekraczającej kulturowe tabu nie są charakterystycznym rysem współczesnej prozy polskiej, już bowiem twórczość Gabrieli Zapolskiej określano jako „studia położnicze” i literaturę brukową".

Przemysław Czapliński analizując kobiecą literaturę współczesną, wspomniał o nowej bohaterce - „Kobiecie Rozproszonej”, kobiecie z ruchomą tożsamością. Bohaterka I. Filipiak, M. Gretkowskiej czy N. Goerke pozostaje „obcą” wszędzie. Jest to także „kobieta samodzielna”, samoświadoma, a w efekcie, jak dowodzi P. Czapliński - „kobieta samowystarczalna”25. Ocena społeczna tej postaci w literaturze jest negatywna, bo społeczeństwo jest patriarchatem. Ucieczka jest możliwa, ale inny, lepszy świat nie istnieje - pisze Czapliński. Samowystarczalna kobieta przegląda się w „lustrze zazdrości kobiet” zamiast w „lustrze pożądania męskiego"26. A przy tym jest nosicielką patriarchatu ${ }^{27}$, od którego niby uciekła.

Kinga Dunin w powieści Tabu i Obciach pokazała nie tylko kwestie tabu, ale codzienność z perspektywy zamiany ról „męskich” i "żeńskich” w rodzinie. Sfera codziennych obowiązków domowych została wydobyta przez Kingę Dunin na powierzchnię narracji, a nie jak to zwykle bywa - ukryta. Kobieta nie musi rezygnować ze swoich wyborów, jest w „,́rodku”, na równych prawach. „Kobieta Środka" usiłuje współrządzić, ale też nie chce być obcą. Niestety, jak zauważa Przemysław Czapliński, prowadzi to do powielania w prozie polskiej przez inne pisarki porzekadła: $z$ chłopem źle, ale bez chłopa - jeszcze gorzej ${ }^{28}$. Wedle P. Czaplińskiego wspomniane konwencje i schematy zdominowały współczesną literaturę kobiet i wpisują się w dyskurs patriarchalny ${ }^{29}$.

Natomiast innego zdania jest Kazimiera Szczuka, która kolejny etap przełomowy dla literatury feministycznej obwieściła w 2008 roku w tekście Rewolucja jest kobieta. Krytyczka z entuzjazmem analizowała utwory Bożeny Keff, Sylwii Chutnik i Doroty Masłowskiej. Podkreślała genealogię matrylinearną wszystkich historii oraz próbę odnowienia znaczeń paradygmatu narodowego, opowiedzenia historii ojczyzny - Polski.

${ }^{23}$ Czapliński, op. cit., s. 102.

${ }^{24}$ Zob. K. Szczuka, Rewolucja jest kobieta, http://www.polityka.pl/kultura/276030,1,rewolucja-jest-kobieta.read [dostęp: 10.07.2012].

${ }^{25}$ Czapliński, op. cit., s. 113.

${ }^{26}$ Ibid., s. 117.

${ }^{27}$ Ibid., s. 118.

${ }^{28}$ [Za:] ibid., s. 124.

${ }^{29}$ Ibid., s. 128. 
Jakie główne tematy pojawiają się u pisarek reprezentujących najmłodsze pokolenie? Jest to codzienność życia kobiet w Polsce, proza życia, krytyczny ogląd rzeczywistości polskiej, ale i globalnej. Dorota Masłowska posługując się oryginalnym, plastycznym językiem, zajmuje się obrazem ponowoczesnej Polski (Wojna polsko-ruska, Paź królowej, Między nami dobrze jest) i młodej generacji (Kochanie zabitam nasze koty). Za nią konsumpcjonizm atakuje Agnieszka Drotkiewicz (Paris, London, Dachau).

Młode twórczynie literatury polskiej, opisując „świat kobiet”, czasem bazują na autobiograficznych doświadczeniach. W ten sposób nierzadko dochodzi do ujawniania najskrytszych tajemnic prywatnych. Marta Dzido napisała aborcyjny „coming out". Temat przerwania ciąży funkcjonuje u niej raczej jako pewien fetysz, bo gdyby nie słowo wstępne, czytelnikowi trudno byłoby odczytać utwór jako literaturę o przerwaniu ciąży. Poetka Justyna Bargielska stworzyła „niestosowne” opowiadania pt. Obsoletki na podstawie kobiecych doświadczeń strat ciąży i własnych dramatów macierzyńskich. Historie niemożliwe do opowiedzenia spisała i poddała życiowo-filozoficznym rozważaniom z perspektywy niedocenianej codzienności. W literaturze polskiej prekursorskie opisy ciąż, porodów, bycia matką pojawiły się znacznie wcześniej np. u Jolanty Brach-Czainy (Szczeliny istnienia) i Anny Nasiłowskiej (Domino. Traktat o narodzinach, Ksiegga poczatku), potem u Manueli Gretkowskiej (Polka), Doroty Terakowskiej (Ono) czy Sylwii Chutnik (Dzidzia, Mama ma zawsze rację). Natomiast poronienia, które są powszechnym doświadczeniem wielu kobiet, nie były dotąd uznawane za szczególnie ważne dla literatury. Sylwia Chutnik konsekwentnie opisuje warszawskie podwórka, codzienne dzieje „samotnych" Matek-Polek, co jest także osobistym doświadczeniem pisarki, anarchistki i osoby prowadzącej fundację dla matek. Ewa Schilling (podobnie jak I. Filipiak) ukazuje miłość lesbijską, czyniąc z tego deklarację swojej seksualności.

Historia współczesnej poezji kobiecej w Polsce czeka na szerokie opracowa$n^{30}{ }^{30}$. Wśród najważniejszych poetek urodzonych w latach 60. minionego wieku wymienić należy: Ewę Sonnenberg, Marzenę Brodę, Annę Piwkowską i Marzannę Bogumiłę Kielar. Rozpoznawalne poetki urodzone dekadę później to: Marta Podgórnik, Julia Fiedorczuk, Agnieszka Wolny-Hamkało i Wioletta Grzegorzewska. Z kolei w pokoleniu najmłodszych poetek, debiutantek warto zwrócić uwagę na twórczość Miłki Malzahn ${ }^{31}$ i Kiry Pietrek ${ }^{32}$. Miłka Malzahn atakuje wi-

\footnotetext{
${ }^{30}$ Por. I. Smolka, Lęki, ucieczki, akceptacje. Dziewięć światów. Wspótczesne poetki polskie, Warszawa 1997; A. Legeżyńska, Od kochanki do psalmistki... Sylwetki, tematy i konwencje liryki kobiecej, Poznań 2009.

${ }^{31}$ Opowiadania Baronowa Późna Jesień (2001), Nie ma mono (2007), powieść Królowa rabarbaru (2004), tom wierszy Rzeczy wydarzone (2001).

${ }^{32}$ Język korzyści (2010), poetka otrzymała Wrocławską Nagrodę Poetycką Silesius 2011.
} 
zją kobiecego świata i jego odczuwania nie tylko słowem, gdyż jest wokalistką i kompozytorką. Z kolei Kira Pietrek szokuje nowym typem bohaterki lirycznej. W jej poezji świat człowieka nie różni się od zwierzęcego, bohaterka zaś wolna od wszelkich ograniczeń seksualnych, rodzinnych, moralnych prowokuje w imię wolności i równości, przy tym kpi z korporacyjnej kultury i przyzwyczajeń.

To, co łączy poetki różnych pokoleń, to autobiografizm, liryzm, prymat codzienności i przeżyć psychicznych kobiet. Nie wszystkie ze wspomnianych twórczyń deklarują feministyczne wartości. Z kolei w prozie „skandalistki” średniego i młodego pokolenia, takie jak: Izabela Filipiak, Kinga Dunin, Manuela Gretkowska, Olga Tokarczuk, Hanna Samson, Ewa Schilling, Marta Dzido, Agnieszka Drotkiewicz, Sylwia Chutnik, otwarcie nazywają siebie feministkami. Inne stanowczo zaprzeczają. Widać, że feminizm jest różnie odbierany i zapewne odmiennie rozumiany.

Krytyka literatury feministycznej w Polsce skupia się wokół kilku głównych postaci, które od lat śledzą dokonania pisarskie z perspektywy feministycznej. Są to: Maria Janion, Przemysław Czapliński, Inga Iwasiów, Kazimiera Szczuka. Obecny stan polskiej literatury kobiet nie świadczy o tym, aby feministyczne idee przeniknęły, zrewolucjonizowały społeczeństwo. Jednym z problemów jest fakt, iż książka nie jest w Polsce popularnym dobrem kultury i nie ma już takiej siły oddziaływania jak w czasach drugiego i trzeciego układu kultury wedle koncepcji Antoniny Kłoskowskiej ${ }^{33}$. Literatura pisana przez kobiety zapełnia niszę, ale ogólnie nie jest „mocnym polem” twórczości literackiej. W oficjalnym obiegu oceniana jest ambiwalentnie przez badaczy literatury. Wydaje się, że wciąż zwartego opracowania krytycznego domaga się dorobek pisarski kobiet $\mathrm{z}$ lat powojennych, z okresu PRL. Trudno też obecnie wskazać choć jedną osobę wśród polskiej krytyki literackiej, która zawodowo, naukowo zajmuje się zjawiskiem współczesnej, feministycznej czy kobiecej - poezji. Są to enklawy twórczości pisarskiej kobiet, które czekają na odkrycie, interpretację. Na równouprawnienie w polu rodzimego kanonu zasługują polskie pisarki.

\section{Podsumowanie}

Okres dwudziestolecia międzywojennego to czas, kiedy pojawił się w literaturze polskiej feminizm wewnątrzpokoleniowy, nakierowany głównie na opis i krytykę patriarchalnego, niesprawiedliwego świata. Autorki szokowały „nowymi”,

${ }^{33}$ B. Sułkowski, „Społeczne ramy kultury” czterdzieści lat później. Pięć modeli komunikacji kulturowej, „Kultura i Społeczeństwo” 2011, nr 2-3, s. 5-34. 
bo kobiecymi tematami, bohaterkami, problemami. Przełamywały stereotypy i zabierały głos w sprawach tak ważnych, jak seksualność, rodzicielstwo, małżeństwo, miłość. W okresie po drugiej wojnie światowej najdonioślejszą próbę „odczarowania" stanowiły tomy wierszy Jestem baba (1972) i Budowałam barykade (1974) Anny Świrszczyńskiej, w których autorka opowiedziała własnym głosem i ,własnym językiem” o powstaniu warszawskim i o codziennym losie kobiet, żon, matek. Jej poezja wówczas szokowała i zbyt atakowała ekshibicjonizmem. Potem o „rewolucji” mówiono w odniesieniu do pisarek związanych z „bruLionem", twórczyń, które w latach 90. prowokowały autobiografizmem, mitologizacją kobiecą, ,innym” językiem.

Literatura najnowsza przechodzi do defensywy, pisarki nie walczą, nie deklarują wprost swych feministycznych nastawień. Możemy zauważyć wprawdzie jakieś strategie feministyczne $w$ tekście, pojawiają się zazwyczaj przy opisach relacji między ,żeńskim” i „męskim” oraz „żeńskim” i ,żeńskim”.

Problematyka feministyczna w polskiej literaturze jest w stanie regresu. Autorki debiutujące w ostatnim dziesięcioleciu mniej wywołują dyskusji, sporów, konfliktów, może też i dlatego mniej w tym obiegu się je dostrzega. Krytycy podkreślają, że współczesna polska literatura jawi się jako „łagodnie feminizująca”. Inga Iwasiów słusznie zauważa, że w literaturze polskiej do rzadkości należą wątki konfrontacyjne, szczególne manifestacje niechęci do męskiej kultury, czy zdecydowana krytyka patriarchatu. Tym samym radykalny feminizm (jak dawniej) nie uobecnia się w polskiej literaturze. Polska proza „łagodnie feminizując”, daje się zaliczyć się do nurtu głównego ${ }^{34}$.

Można zapytać, czy we współczesnej literaturze kobiet w Polsce widoczny jest feminizm międzypokoleniowy, wewnątrzpokoleniowy ${ }^{35}$. Sądzę, że zjawiska takiego zaobserwować nie można. Feministki „pierwszej fali” już nie żyją, ich utwory odchodzą nierzadko w zapomnienie. Ważne nazwiska pisarek - feministek „wypadły” z oficjalnego obiegu literackiego. Przyglądając się różnym okresom literatury XX i XXI wieku można wyraźnie dostrzec brak ciągłości tradycji feministycznych w twórczości kobiet. Pokolenie pisarek dwudziestolecia międzywojennego wniosło nowe tematy do literatury polskiej, zrywało z hipokryzją obyczajową, edukowało kobiety. Pokolenie kobiet „bruLionu” rozpoczęło nową erę w literaturze kobiet - pojawiły się ważne „książki feministyczne”. „Pokolenie Ikei" jakby zarzuca te tradycje.

${ }^{34}$ Zob. I. Iwasiów, Być kobietą. Literatura feministyczna w Polsce, Za: http://www.instytutksiazki.pl/pl, ik, site,8,8,1.php. [dostęp: 10.07.2012].

${ }^{35}$ Por. A. Galant, Na marginesie literackiej aktywności autorek najmłodszych, [w:] Dwadzieścia lat literatury polskiej 1989-2009, red. D. Nowacki i K. Uniłowski, Katowice 2011. 
Na koniec warto odpowiedzieć na zasadniczą kwestię: czy literatura w ogóle ma płeć, czy też pisarze dzielą się na dobrych i złych. Odpowiedzią jest odrębność literackich projektów kobiet, ich indywidualność, która zapewnia im poczytność. Warto jednak zauważyć, że wielkie wydawnictwa, dominujące na rynku, jakby nie interesują się piszącymi, młodymi kobietami (pisarki wydają utwory w wydawnictwach małych, niszowych).

Wypada też postawić pytanie o polskich artystów-mężczyzn oficjalnie deklarujących sympatię dla feminizmu. Wśród twórców kultury i sztuki być może powinno ich być więcej niż w innych grupach zawodowych.

Od lat z polskim patriarchatem wojują przedstawiciele różnych nauk, np. Wiktor Osiatyński, Przemysław Czapliński, Stanisław Obirek. Pod listem otwartym Wiktora Osiatyńskiego opublikowanym na łamach prasy w 2009 roku pt. Dlaczego jestem feminista, podpisało się 69 mężczyzn reprezentujących różne grupy pracowników, naukowców, dziennikarzy, polityków (tylko przedstawiciele partii Zieloni 2004) ${ }^{36}$. Wśród osób, które wyraziły poparcie i określiły się feministami, znaleźli się reżyser Laco Adamic artysta sztuk plastycznych Mirosław Bałka oraz literaci: Andrzej Bart, Tomasz Białkowski, Jarosław Błahy, Jan Gondowicz, Tomasz Piątek, Janusz Rudnicki, Wojciech Stamm, Mariusz Sieniewicz, Janusz Leon Wiśniewski. W grupie uwidoczniła się przewaga pisarzy. Żaden z nich nie uzasadnił swojego poparcia. Warto wspomnieć, że Janusz Wiśniewski korzystając z możliwości, jakie stawia przed twórcą czwarty układ kultury oparty na interaktywności medialnej, napisał dwa dzieła, współdziałając z internautami i internautkami. Problematyka płci zainteresowała Mariusza Sieniewicza (Spowiedź śpiącej królewny). W jego utworach pojawiły się bohaterki, nie są one jednak głównymi postaciami, tak jak ma to miejsce w prozie Janusza Leona Wiśniewskiego (Bikini, Martyna, Łóżko, Na fejsie z moim synem) czy u Andrzeja Barta w Rewersie. U pozostałych autorów-feministów trudno znaleźć ideologiczne odzwierciedlenie poparcia dla feminizmu w twórczości literackiej (choćby w aspekcie problemów, wątków, postaci, języka).

Opis świata polskich kobiet pozostaje działalnością pisarek. Nie jest to jednak wspólny front działalności literackiej. Twórczość starego i średniego pokolenia piszących emancypantek, feministek pozostaje „,nieprzepracowana” przez kolejne pokolenia. Młode pisarki rzadko wspominają w wywiadach o feministycznych ideach. Możemy raczej mówić o odruchach feministycznych w tekście oraz o pewnych indywidualnościach twórczych. Tym samym literatura feministyczna w Polsce wydaje się wciąż nieoswojonym czy nawet „na nowo” obcym zjawiskiem kulturowym.

\footnotetext{
${ }^{36} \mathrm{http}: / /$ wyborcza.pl/1,82949,6737623,A_czy_ty_jestes_feminista_html [dostęp: 10.07.2012].
} 


\section{SUMMARY}

The subject of discussion in this sketch is first of all feminist themes present in Polish women's literature. The text considers the following questions: whether the phenomenon of feminist literature exists in Poland; whether feminist themes are characteristic only of women's art; what feminisms are present in women's literature? Sociological studies show that feminism is not socially approved even among women who experience gender inequalities. The denial of the positive role of feminism still persists, and there is a deeprooted antifeminist attitude stemming from ignorance and stereotypes. Many years ago Ewa Malinowska argued that the feminist movement in Poland consisted in the activity of individuals rather than the collective work of social activists. The native roots of literature associated with feminism are sought in Narcyza Żmichowska's Enthusiasts (Entuzjastki) group. The women writers participating in this movement were involved in political and educational activities. After World War One, after women were granted voting rights and right to education, women's literature in Poland touched on many social and moral taboos, including sexual, such as pregnancy, maternity, abortion, or marriage (G. Zapolska, Z. Nałkowska, M. Kuncewiczowa, P. Gojawiczyńska, I. Krzywicka, A. Gruszecka, H. Boguszewska, and others). World War Two and the period of People's Poland pushed feminist ideas and women's important problems and subjects into the deep background. The situation changed after 1989 with the debuts of women writers who not only described female experiences but also openly declared their sympathies towards feminism in interviews (e.g. Manuela Gretkowska, Izabela Filipiak, Olga Tokarczuk, and Natasza Goerke). Contemporary literature is not aggressive, however: women writers do not fight and do not openly espouse feminist attitudes and values. 